\title{
GERMAN INFLUENCE ON ESTONIAN AND BALTIC GERMAN CORPS TRADITIONS IN TARTU
}

\author{
Tiina METSO
}

Department of Contemporary History, University of Helsinki, Finland; tiina.metso@ helsinki.fi

This article looks into the German effect on the traditions of Estonian Corps in Tartu, both Baltic German and Estonian. The process of actively denouncing a tradition seen as German is discussed in case of the sword duels, the mensuur. The other example, the song tradition, shows how only the language of songs was changed, not the meaning of the lyrics. And the songs were still sung in the old fashion.

Written material on Baltic German and Estonian student Corps is limited. Besides the archives, most material on Corps is in the form of albums and scattered memoirs, almost always without references to any sources. These albums chronicle important events as well as everyday activities of the Corps. But as any autobiographical work often written many years after the actual events, some details cannot be completely trusted as different versions of the same events may contradict each other.

Collective commemorative albums, like Spes Patriae ${ }^{1}, 50$ th anniversary album ${ }^{2}$ of Eesti Korporatsioonide Liit and many others, have the same profound disadvantages. They chronicle the history of a certain organization, based on the organization's collective memory voiced often by a single writer, but too often have only a list of used literature instead of more specific footnotes identifying the sources of certain data, thus rendering it next to impossible to find the original source. But being one of the few sources of information, these albums and other collective works are being treated as the official history of the Corps.

1 Piirimäe, H. (ed.). Spes Patriae. Tallinn, 1996.

2 Arro, K. (ed.). Eesti Korporatsioonide Liit. Toronto, 1966. 
These albums are still often the only remaining sources of information on the internal life of a Corps, and can well be used in research bearing their limitations in mind. Some data can be corroborated with secondary sources like newspapers and official publications, other data thru comparison between different Corps. The albums usually contain descriptions of events and customs, and it is very rare to find any analytical or even comparative material in them.

The material on Corps placed in Estonian archives has luckily been largely preserved, and has provided valuable information on all aspects of Corps life and traditions for this article. The Estonian National Archive in Tallinn as well as the Historical Archive in Tartu have collections on almost all Estonian Corps and on some Baltic German Corps as well. Comparison between the Corps has proven to be an especially solid method to overcome the missing materials in individual Corps material. These gaps often consist of personal information on members, like curriculum vitae and photographs, as well as of lists of members and former members. It is quite understandable that such material was not turned over as the Corps were banned and liquidated. The administrative material seems to be more complete, lacking only the most intimate documents of a Corps, such as the founding charters and sets of rules (including the fencing, mensuur and duel rules).

Academic work on Corps is rare, but some do exist, mainly in Germany and/or on German Corps. G.G.S. Weber wrote his Ph.D. thesis on German Corps in the Third Reich ${ }^{3}$, and Martin Biastoch did his Bachelor thesis on fencing for the University of Tübingen. ${ }^{4}$ These sources, indirect as they may be, provide some information on German student traditions and on Corps in general, and are used in comparative capacity for this article, unless specific information is available. In Estonia Ruut Bender has written her Masters thesis in German philology on Baltic German student language in Tartu. ${ }^{5}$ The work naturally emphasizes linguistic aspects, but provides also valuable information on the context of the language, especially from sources in German. Some minor papers and works have also been written, but being more like chronicles they do not unfortunately provide new information.

This work looks into traditions with German roots, how they became an established part of Baltic German and Estonian student Corps. The research has aimed to find as many original sources as possible instead of using the references in other publications in order to find the roots and development of the German tradition into an Estonian tradition. It may well be said that the framework of Corps is clearly of German origin, but the contents are Baltic. The mensuur (duel) and song traditions are just two compact case examples of the German influence on Estonian student Corps in Tartu.

3 Weber, G. G. S. The German Student Corps in the Third Reich. London, 1986.

${ }^{4}$ Biastoch, M. Das studentische Mensur- und Duellwesen im Kaiserreich. Tübingen, 1990.

5 Bender, R. Die Dorpater Studentensprache und die deutschbaltischen studentischen Korporationen and der Kaiserlichen Universität Dorpat im 19. Jahrhundert - die baltische Eigenart in der deutschen Studentenkultur. Tartu, 2002. 


\section{MOBILE TRADITIONS IN TIME AND PLACE}

Quite often mobility is seen as a movement of concrete matters, like people, materials and goods. The mobility of ideas, of traditions and manners can be harder to trace and to prove, unless there is a specific group to follow and observe.

Since medieval times the students have been mobile elements of the society. At European borderlands young men had to leave their homes for years as they aimed for an academic education in old European universities like Paris. They were the true followers of the 'Ubi bene, ibi patria' principle. Other such mobile groups of people were for example artisans, troubadours and tradesmen.

During the early years Baltic German students from noble families did not embrace the University of Tartu (Academia Gustaviana), founded in 1632, and thus the university students were mainly from Sweden, Finland and Ingermanland. ${ }^{6}$ The Baltic German families preferred German universities like Königsberg, Rostock and even Leiden. When the number of Baltic German students rose at the University of Tartu, nobility with means still used the opportunity to send their youth to German universities. ${ }^{7}$ Before the 1802 re-opening of the University in Tartu after the Great Northern War, the young men of Courland, Estonia and Livonia acquired their academic education mainly in German universities.

The Imperial University of Tartu (also known as Jurjew and Dorpat) had a stronger contingent of Baltic German students from the early 1800s. The Baltic provinces of Courland, Estonia and Livonia were dominantly German in upper echelons, linguistically as well as culturally. The feeling of national awakening was rising among the students in Germany. The Baltic German families were asked by the Russian Imperial authorities to bring their children back to Tartu from the radical and sometimes even revolutionary German universities. ${ }^{8}$ As the young Baltic students moved to their Baltic Alma Mater in Tartu, they took with them many ideas, traditions and principles from the German universities. ${ }^{9}$

The German influence in the Baltic countries as well as in the Russian empire was also increased by frequent influx of university teachers and professors, as well as by the 'academic overproduction' of German universities, which provided plenty of academically educated people for the whole Russian empire. ${ }^{10}$ Thus the ideas and traditions of student life moved geographically on a wider front from Germany to Tartu and then on to Riga. ${ }^{11}$

Siilivask, K. (ed.). Tartu ülikooli ajalugu 1632-1982. Tallinn, 1985, 23.

7 Siilivask, K. (ed.). Tartu ülikooli ajalugu 1632-1982, 33. 1632-1710 the University of Königsberg had 524 Baltic students, and 1656-1716 Rostock had 181 and Leiden 112 respectively.

8 Siilivask, K. (ed.). Tartu ülikooli ajalugu 1632-1982, 74.

9 Krause, P. O alte Burschenherrlichkeit. - Graz, 1997, 152-153.

10 Siilivask, K. (ed.). Tartu ülikooli ajalugu 1632-1982, 61. Before the Russification process in 1889 the University of Tartu had 3 Russian, 21 German and 19 Baltic German professors. In 1900 there were 11 German and 43 Russian professors. - Ibid, 116-117.

11 For example see Festschrift Concordia Rigensis 1869-1969. Hamburg, 1969, 12-13. 
The same traditions became a part of living student tradition in Tartu, a tradition which was kept and passed on within Corps, from generation to generation. The traditions were adapted to changing times, but the changes were generally minor and the main principles of German traditions remained basically the same for several decades. Many old features were in existence when the Estonian Corps were re-born in the late 1980s, and they were also adapted and accepted as a part of the modern Corps tradition after a 50-year period of non-existence of living student Corps culture in Tartu.

\section{GERMAN DUELING STUDENTS}

The tradition of dueling was widely spread in German society of the 19th century. The aristocrats dueled, the officers dueled and so did the students. It was a well-known tradition, but used only in limited social circles. It must be noted that many officers of the German army up to World War II were both aristocrats and former university students. ${ }^{12}$ Thus it is often quite impossible to separate the influences of these three similar overlapping, yet different traditions.

The students' duel, mensuur ${ }^{13}$, seemed to have been more acceptable and tolerable for the public as a presentation of student aggression than the dueling tradition of, for example, the officers. The tradition of dueling was defended by the Germans by its educational aspects: it would teach the youth restraint and courage, as well as being generally character building. The Corps could justify duels as educational tools, to prove courage in face of pain, mutilation or even death. ${ }^{14}$

The Corps members were always a minority in the student body. And among the Corps members the nobility were a minority within a minority. But this noble Corps minority played a major role in the student world by being the ultimate trendsetter. This way the international aristocratic tradition of solving disputes of honor with duels was spread to the growingly bourgeois student body of German universities and became undisputedly a student tradition. Thus a clear minority has had a definite influence on the standard behavior of the majority. Peter Gay calls this 'the triumph of status over statistics'. ${ }^{15}$

The importance of the mensuur tradition is well shown in the fact that the oldest Baltic German student organization in Estonia, called Curonia, starts its history

12 In February 1943, Generalfeldmarschall von Kluge challenged Generaloberst Guderian to a duel because of their military differences and rivalry. Rooney, D. Military Mavericks. London, 2001, 135. SS-Sturmbannführer Otto Skorzeny had studied engineering in Vienna and was a well-known aggressive duelist, who was said to have participated in 15 sabre duels and had a very visible scar as a memento. Rooney, D. Military Mavericks, 209 and www.spartacus.schoolnet.co.uk/GERskorzeny, 11.3.2004.

13 In Estonian, 'Mensur' in German.

14 Gay, P. The Cultivation of Hatred. New York, 1993, 31.

15 Gay, P. The Cultivation of Hatred, 16. 
from a mensuur on 8.9.1808 where their native Curonian colors were first used in this context. Many of these Curonian students came to Tartu from the University of Göttingen, from which they were expelled as a result of too many mensuurs. ${ }^{16}$ Some of them had left the University of Jena at the turn of the 19th century, as the anti-duel movement gained momentarily momentum and pressure was on the habitual duelists. ${ }^{17}$ They brought with them from their first alma mater the strong student mensuur tradition which came to be an essential and important part of the Corps life at the University of Tartu for well over 100 years. It should be remembered that at the time of founding Curonia, the university statutes from 1803 still forbade all student organizations. ${ }^{18}$

The traditions and rules of student duels and mensuurs for both Baltic German and Estonian Corps remained basically the same for almost 140 years in the Baltic countries, up to the latest rules from the pre-WW II years. ${ }^{19}$

As a basic rule of thumb, a duel is fought with pistols and a mensuur with swords. ${ }^{20}$ Sometimes mensuur is used solely as a name for a form of duel with swords. ${ }^{21}$ In English, the word 'duel' covers both kinds of settling the score. Therefore this text will use the word 'duel' for a duel with pistols, and 'mensuur' for a duel with swords.

\section{GUARDING THE HONOR}

To understand the whole tradition the two main terms in this process are honor, 'Au' ${ }^{22}$, and satisfaction, 'Satisfaktsioon' ${ }^{23}$ from the Corps' point of view.

Honor needs to be protected and guarded, but it also needs defining. The member Corps of the Eesti Korporatsioonide Liit (the Union of Estonian Corps), $E K L$, have made a short list of people and things which need to be protected from insults in an academic context. Any and every member of an $E K L$ member Corps is obligated to react to any insult aimed at them personally, at their co-members, at members of EKL or its union of senior organizations, Eesti Korporatsioonide Vilistlaskogude Liit (EKVL), at EKL or EKVL as an organization or at Estonian people in general. Even insults aimed at a person who is not present at the time can require a reaction. ${ }^{24} \mathrm{~A}$ most vital part of the honor of a Corps are its symbols: colors in the form of a hat and a band of an individual member, as well as the flag

\footnotetext{
16 Wittrock, H. Vom Bursenknecht bis zum Farbenstudenten. Riga, 1924, 52.

Gay, P. The Cultivation of Hatred, 18.

Siilivask, K. (ed.). Tartu ülikooli ajalugu, 68-69.

19 EKL, auasjade lahendamise kord, 10.2.1937. - Eesti Ajalooarhiiv (EAA), 1759-1-92.

20 Tõnisson, I. Tartu üliõpilasorganiseerumise ajaloost. - In: Üliõpilase käsiraamat. Tartu, 1931, 119.

21 Postimees, 27.2.1933.

22 In Estonian, 'Ehre' in German.

23 In Estonian, 'Satisfaktion' in German.

24 EKL, auasjade lahendamise kord, 10.2.1937. - EAA, 1759-1-92, § 1.
} 
and the coat of arms. Every Corps has its own tricolor, unique to one Corps per country. ${ }^{25}$ Stealing, damaging or treating them disrespectfully is still a huge insult to a Corps.

There had to be a reason behind every duel and mensuur. ${ }^{26}$ The proper reaction to an insult was to demand satisfaction, the cleansing of honor, from the insulting party. ${ }^{27,28}$ To give satisfaction was the duty of every student with a good name, stated the Offizieller Paukkomment für die Deutschen Universitäten und Hochschulen (Official Fencing Rules for German Universities) from 1907 which were applicable also in Tartu (Dorpat in German). ${ }^{29}$ If an insulted person does not react to an insult with a demand for satisfaction, the demand could and should be made on his behalf by another person, most likely a member of the same Corps or of another EKL Corps. ${ }^{30}$

After the original insult and a demand for satisfaction the matter moved on according to traditional protocol. Both parties chose a middleman, and after that they had no direct personal contact with each other. First the matter was taken to an honor court ${ }^{31}$ which decided on the guilt of both parties as well as on the level of the insult and whether the insult required satisfaction with weapons or if an apology was enough. In some cases the decision was left to the winner, the insulted party. ${ }^{32}$ It is often emphasized that an apology, satisfaction with words, was just as honorable as a duel or mensuur, satisfaction with weapons. ${ }^{33}$ Giving satisfaction did not per se equal giving satisfaction with weapons. ${ }^{34}$ An apology was the only form of honorable giving of satisfaction for the anti-duelists, the non-fighting Corps members. ${ }^{35}$ Both duelists and anti-duelists existed within a Corps, at the same time. ${ }^{36}$

If an honor court found that an alleged insult was a result of a misunderstanding or that a demand for satisfaction was without a valid reason, the matter could be ended when the demander took his demand of satisfaction back by using certain phrases. ${ }^{37}$ Sometimes the whole matter of honor and satisfaction became

25 See Haljaspõld, H. Tudengi sõnastik. Tartu, 1935.

26 Biastoch, M. Das studentische Mensur- und Duellwesen im Kaiserreich, 31.

27 Biastoch, M. Das studentische Mensur- und Duellwesen im Kaiserreich, 32.

28 EKL, auasjade lahendamise kord, 10.2.1937. - EAA, 1759-1-92.

29 Setter, J. Paukkomments, Schriftenreihe der Studentgeschichtlichen Vereinung des CC, Jever, 1986, 16.

30 EKL, auasjade lahendamise kord, 10.2.1937. - EAA, 1759-1-92, § 7.

31 In Estonian, 'Aukohus', in German 'Ehrengericht'.

32 EKL, auasjade lahendamise kord, 10.2.1937. - EAA, 1759-1-92.

33 Spohr, E. 'Aus dem Leben des Corps Curonia Goettingesis'. - In: Jahrbuch des baltischen Deutschtums, 1964. Hamburg, 1963, 132.

34 Wachtsmuth, W. Wesen, Aufbau und Bedeutung der ehemaligen Deutsch-baltischen Studentischen Korporationen. Sonderdruck aus Einst und Jekt, 1956, 47.

35 Wachtsmuth, W. Wesen, Aufbau und Bedeutung der ehemaligen Deutsch-baltischen Studentischen Korporationen, 51.

36 Korp! Revelia, Mag. paucandi yearly report, 4.5.1936. - EAA, 1752-1-10.

37 EKL, auasjade lahendamise kord, 10.2.1937. - EAA, 1759-1-92. 
unsolvable, as both parties as well as their witnesses were unable to remember practically anything of the incident. ${ }^{38}$ Alcoholic beverages may have had something to do with these situations.

Some Estonian Corps denounced the practice of achieving satisfaction with weapons, but kept on fencing as a sport and as a tradition. ${ }^{39}$ Younger members were expected to acquire the skills in fencing by attending fencing classes regularly, often several times per week. ${ }^{40}$ These classes were conducted by magister paucandi, the fencing master of the Corps as well as a fencing teacher. When the younger members had acquired the required skills in fencing and its traditions, magister paucandi would declare them as wäljapaukinud ${ }^{41}$, one who has fenced himself free and does not have to be present at fencing classes anymore. ${ }^{42}$ Even anti-dueling members had to fence themselves free in the Baltic German Corps, and thus show their knowledge of traditions as well as their skills in fencing. ${ }^{43}$ Older members were expected to come to the classes if they were preparing for a mensuur. ${ }^{44}$ Magister paucandi registered members who did not acknowledge duels, the anti-duelists, as well as excused the members with adequate skills from further fencing classes. ${ }^{45}$

\section{S MENSUUR AND DUEL RULES IN TARTU}

After the honor court the whole matter could still be ended with honor by an apology. ${ }^{46}$ If a satisfaction with weapons was chosen, the events would follow certain rules. Both parties would need a secundant, usually a member of the same Corps, as well as a witness. An impartial party - from a third Corps - was needed to run the event according to the rules. Two doctors, or advanced level medical students, were also needed. If any of the required persons was not present at the chosen site, the mensuur could not be held. In a sword mensuur spectators from the two dueling Corps were allowed to be present.

The mensuur officially started when the impartial official gave the last speech pleading for a peaceful solution. He also reminded the duelists that the act in which they were about to engage was illegal. This speech was often seen as a pure formality. The impartial official also reminded the duelists of the mensuur rules.

\footnotetext{
38 Appeal from Juhan Luik to EKL, 14.12.1937. - EAA, 1759-1-92.

39 EKL esinduskogu protokoll $\mathrm{nr}$ 146, 28.11.1939. - EAA, 1761-1-13, 96.

40 See Korp! Rotalia, Mag. paucandi diary. - EAA, 1757-1-217.

41 In German 'Herauspaukt'.

42 Korp! Revelia, Paukbuch. - EAA, 1752-1-55, 68.

43 Wachtsmuth, W. Wesen, Aufbau und Bedeutung der ehemaligen Deutsch-baltischen Studentischen Korporationen, 49.

44 Korp! Revelia, Mag. paucandi yearly report, 4.5.1936. - EAA, 1752-1-10.

45 Korp! Revelia, Paukbuch. - EAA, 1752-1-55, 68.

46 Korp! Revelia, Mag. paucandi yearly report, 4.5.1936. - EAA, 1752-1-10.
} 
The mensuur started after the first command: 'Lahti!" ${ }^{47}$, free. Only strikes were allowed, no slicing or stabbing. Hits were announced by the secundant of the opposite sides, in a tie the impartial decided. The mensuur ended after a certain amount of rounds which had been agreed upon earlier, or if a party was rendered incapable due to a serious injury. In order to assess the level of injury, a medical examination was performed after each hit.

In a duel with pistols no spectators were allowed, and each party needed two secundants. Only shots below the hips, mainly in the feet, were allowed. Body shots were allowed only in cases of very serious insults and needed an earlier agreement. Both parties had usually only one shot, and in any case there could never be more than three rounds of shots. Shots were allowed according to relevant commands only. The secundants had the right to fire at the party who broke the rules of the duel. The duel ended when the time for shooting ended, regardless of whether the shots had been fired or not. The shooting could not be repeated within the same honor process. ${ }^{48}$

\section{ACCESSORIES FOR A MENSUUR IN TARTU}

The duelists wore stylish tail coats for duels with pistols ${ }^{49}$, or for mensuurs with swords, a fencing gear called takelaaz ${ }^{50}$, where the colors of their respective Corps were visible. ${ }^{51}$ In case of a mensuur between members of the same Corps ${ }^{52}$, the colors were hidden as the colors of same Corps could not fight against each other. ${ }^{53}$ Besides a light white shirt, takelaaz consisted of a protective helmet that covered the eyes and the face, a neckband, a padded glove and a heavy protective belt with padding for the lower body. ${ }^{54}$ Legs were protected with thick leather pants. ${ }^{55}$ The Corps colors were also visible in sword handles as well as in secundants' Corps hats. ${ }^{56}$

Takelaaz was the property of a Corps, and its members used it in mensuurs. ${ }^{57}$ If a Corps did not own a takelaaz, it had to be borrowed from another Corps. ${ }^{58}$ The swords came always from the Corps of the duelists, and a Corps usually had a wider selection of swords, starting from ceremonial swords and ending with

In Estonian, 'Los!' in German.

48 See Postimees, 27.2.1933 on whole process.

49 Postimees 21.2.1933.

50 In German 'Takelage'.

51 Blanckenhagen, H. v. Studienjahre in Dorpat vor dem 1. Weltkrieg. - In: Göttinger baltische Corps Blätter (1972: 23), 15.

52 In German 'Intern Mensur'.

53 Grünewaldt, O. Üliõpilasaeg. Tallinn, 2000, 12.

54 Korp! Ugala, Mag. paucandi yearly report 1931. - EAA, 1759-1-42, 16.

55 Grünewaldt, O. v. Üliõpilasaeg, 12.

56 Blanckenhagen, H. v. Studienjahre in Dorpat vor dem 1. - Weltkrieg, 15.

57 Korp! Ugala, Mag. paucandi yearly report 1931. - EAA, 1751-1-42, 14.

58 Korp! Revelia, Mag. paucandi yearly report, 4.5.1936. - EAA, 1752-1-10. 
mensuur and practice swords. ${ }^{59}$ The traditional mensuur sword was called 'rapiir', rapier, but it was actually a 'Schläger', a straight-edged weapon without a sharp point. The original rapier with a sharp point was abandoned in Germany by 1840, after too many punctured lungs. ${ }^{60}$ In Tartu the sharp-pointed rapiirs were used for ceremonies, where a sharp point was essential, and they were called 'värvirapiir', rapiir with colors, and the dull-pointed ones were called 'mensuurrapiir'. ${ }^{61}$ The Paukkomment fencing rules of 1907 define a 'Korbschläger' with a large hand-shield as the weapon to use in Tartu, as well as in Göttingen from where the tradition came to Tartu. ${ }^{62}$ These rules from the Paukkomment applied only to the Baltic German Corps of Tartu, but did have an effect also on the Estonian Corps.

\section{THE LAST DEADLY DUEL IN TARTU}

According to the available sources the last deadly pistol duel in Tartu took place in 1933. The actual duel was held on 18 February, early in the morning. ${ }^{63}$ The participants were members of two Baltic German Corps, Oswald Schmidt from Estonia ${ }^{64}$ as the challenger and Friedrich 'Fritz' von Walter from Livonia ${ }^{65}$ as the challenged. Oswald Schmidt was born in $1889^{66}$, and he later became a professor in Germany. ${ }^{67}$ Friedrich von Walter was born in 1907 and was a student of veterinary science. ${ }^{68}$

The reason of this duel was said to be domestic, according to an article in Postimees on 21.2.1933, which said that Schmidt visited Walter at his home and slapped his face, the ultimate cause for a duel. This started a due process with an honor court, which decided that the matter will be settled with a duel within 4 months. In the morning of 19 February the duelists with their secundants, all dressed in tail coats, left in carriages to the assigned place in the forest of Worbuse, not far from Tartu.

The preparations went according to the tradition and protocol. The distance of 15 steps was measured between the duelists, and the duel started. Two shots were fired, and Walter collapsed as a result of a hit. The article goes on to mention that Walter was so irritated or upset that he missed his shot ${ }^{69}$, which may sound

\footnotetext{
59 Korp! Revelia, Paukbuch. - EAA, 1752-1-55, 2.

60 McAleer, K. Dueling. New Jersey, 1994, 121.

61 Korp! Revelia, Paukbuch. - EAA, 1752-1-55, 2.

62 Setter, J. Paukkomments, Schriftenreihe der Studentgeschichtlichen Vereinung des CC, 27.

63 See Postimees, 21.2.1933.

64 Album Estonorum von 1939 (1976), 23.

65 Album Academicum Universitatis Tartuensis II. 1918-1944 (1994), 534.

66 Album Academicum Universitatis Tartuensis I. 1889-1918 (1988), 26.

67 Album Estonorum von 1939 (1976), 23.

68 Album Academicum Universitatis Tartuensis II. 1918-1944, 534.

69 Postimees, 21.2.1933.
} 
surprising as he was a member of a shooting society. ${ }^{70}$ Walter, seriously wounded, was rushed to Mellini hospital in Tartu, where he later died.

Schmidt reported the events to the authorities, who started an investigation into the matter. If Walter had died on the duel spot, it would have most likely brought a prison sentence of 6-8 years for Schmidt, but as Walter died later from his wounds, Schmidt was the only one left expecting a sentence of 2-4 years for dueling, meant for both parties of a duel. ${ }^{71}$

As the case went to court it that Schmidt had fled the country in order to avoid the court and the certain conviction. The court sentenced him in absence to two years imprisonment. He also lost his bail of 1000 crowns. The impartial zur Mühlen as well as the two secundants Sellheim and Hesse were released. ${ }^{72}$

\section{BALTIC MENSUUR RULES COMPARED WITH GERMAN RULES}

The main differences between Baltic German Corps and Corps of the German Kaiserreich, and later with the Third Reich, were quite significant regarding the tradition of duels and giving satisfaction with weapons. The Corps in Tartu, both Estonian and Baltic German, had within one Corps both members who chose to participate in duels, the duelists, as well as those who did not take part in them, the anti-duelists. ${ }^{73}$ The German names for these members are 'Schlagende' and 'Nichtschlagende' ${ }^{74}$ This rule of the freedom of conscience was presented in Tartu already on 17 May $1847^{75}$, when an apology became officially the only kind of satisfaction that could be demanded from an anti-duelist. ${ }^{76}$ Until that, every honorable student was expected to be a duelist. ${ }^{77}$ Anti-duelists had to announce their view to their own Corps and then be exempted from dueling. ${ }^{78}$ A Corps member had to take an official stand on this matter; otherwise it would have been possible to declare oneself anti-duelist when an occasion arose. These stands were noted with the participants' names in the protocols of the honor court. $^{79}$

70 Funeral announcement by Estonian Shooting Society for its member Fritz Walter. - Postimees, 22.2.1933.

71 Postimees, 21.2.1933.

72 Päevaleht, 21.10.1933.

73 Grünewaldt, O. v. Üliõpilasaeg, 12.

74 Wachtsmuth, W. Wesen, Aufbau und Bedeutung der ehemaligen Deutsch-baltischen Studentischen Korporationen, 47.

75 Siilivask, K. (ed.). Tartu ülikooli ajalugu 1632-1982, 1985, 76.

76 Wittrock, H. Vom Bursenknecht bis zum Farbenstudenten, 64.

77 Wittrock, H. Vom Bursenknecht bis zum Farbenstudenten, 69.

78 Korp! Revelia, Paukbuch. - EAA, 1752-1-55, 68.

79 Appeal from Juhan Luik to EKL, 14.12.1937. - EAA, 1759-1-92. 
The Estonian and Baltic German Corps in Tartu did not have the tradition of 'Bestimmungsmensur', which was quite common in Germany. ${ }^{80} \mathrm{~A}$ 'Bestimmungsmensur' is a planned mensuur, by mutual agreement, which was a required element in the German Corps. It meant that a member of a Corps needed a certain number of pre-arranged mensuurs with members of other Corps in order not to fall into dishonor. In these mensuurs only strikes were accepted, no stabbing or thrusting was allowed. ${ }^{81}$ This type of mensuur was introduced to Baltic German Corps during the 1950s as they joined German Corps Cartells like Kösener Senior Convents Verband (KSCV) in Germany. ${ }^{82}$ Other traditional types of duels and mensuurs were already forbidden in Germany, where the Baltic German Corps re-started their activities after WW II. ${ }^{83}$ In a 1950 decision by the KSCV Congress in Germany, any Corps member who was not already a senior member was expected to have at least one mensuur in order to get the right to wear Corps colors, or leave the Corps. ${ }^{84}$

In German mensuurs the target areas were mainly the head and the face, other body parts were well protected. ${ }^{85}$ Despite the fact that the face was a target area, special protective goggles were used to cover the eyes and leather straps protected the ears from being cut off. In Tartu, the head as well as the eyes and ears were protected with a metal-enforced leather helmet, and target areas were the shoulders, upper arms and the upper part of the chest. ${ }^{86}$ The target areas were covered only by a thin white linen shirt.

\section{DENOUNCING THE TRADITION OF GIVING SATISFACTION WITH WEAPONS}

During the 1930s most Estonian Corps were still, at least formally, practicing the traditional mensuur. But actual mensuurs, not to mention duels, took place very seldom, as it was considered more appropriate to solve misunderstandings verbally and with an apology. Active anti-duelists also contributed to the reduction of the number of mensuurs, as they had to resolve situations without the use of weapons. ${ }^{87}$

Korp! Ugala and Korp! Fraternitas Tartuensis had with internal decisions banned mensuurs already in $1936 .{ }^{88}$ In November 1939 the oldest Estonian Corps, Vironia, announced openly that since the Corps decision on 25 September the

\footnotetext{
80 Spohr, E. Aus dem Leben des Corps Curonia Goettingesis, 132. 
same year, its members were forbidden to participate in mensuurs and that mandatory classes of fencing had ended. The letter to other Corps also stated that already set could be held. The reason for this ban was that the tradition was seen as an outdated relic in present times and in the view of the future, and that Korp! Vironia wanted to avoid situations in which real life and borrowed traditions might conflict. ${ }^{89}$

Korp! Rotalia made a similar decision on 11 November 1939, emphasizing the ideal unity of the EKL. All Corps members were forbidden from having mensuurs with members of other EKL Corps. ${ }^{90}$ The Baltic German Corps were not mentioned as most of the Baltic German population of Tartu had left Estonia for Germany in the Umsiedlung, mainly in October 1939, and the Corps were liquidated due to lack of members. ${ }^{91}$ Next Corps to reach similar decision on mensuurs was Korp! Leola $^{92}$ in Tallinn, which in a circular letter to other Corps on 26 April 1940 announced that their members were forbidden to participate in mensuurs. ${ }^{93}$

\section{JOINT PROCESS TOWARDS DENUNCIATION}

$E K L$, the Union of Estonian Corps, had discussed the question of a joint denouncing of duels and mensuurs in its Esinduskogu, the Representative Board, meeting on 10 October, 1939 after Korp! Vironia's decision became public in academic circles ${ }^{94}$, and later even in newspapers. ${ }^{95}$

The matter of giving satisfaction was again brought up in the next meeting on 22 November, where it was stated that Korp! Vironia and Korp! Rotalia had already given written statements on the issue, and that Korp! Ugala had done the same already in 1936, the same year when Korp! Fraternitas Tartuensis had also forbidden mensuurs. Korp! Fraternitas Liviensis had also reached a decision which banned mensuurs. The decision on the matter was moved to next meeting in order to get official opinions from all the member Corps as it was impossible for the EKL to decide such a problem without all eight member Corps agreeing. ${ }^{96}$

The next meeting was held on 28 November 1939, and the matter of duels and mensuurs was duly brought up. The opinions varied, while most of them opposed duels and mensuurs between the member Corps, the standpoints on fencing classes were mainly seen as internal matters of each Corps and thus outside the jurisdiction of the EKL. Korp! Sakala and Korp! Revelia had decided to accept and follow the EKL decisions on mensuurs. ${ }^{97}$ Several propositions were

89 See Korp! Vironia letter to Korp! Väinla, 11.11.1939. - ERA, 2035-1-1, 107.

90 Korp! Rotalia letter to EKL, 1939. - EAA, 1757-1-16.

91 Postimees, 4.11.1939 and 7.11.1939.

92 Not a member of the EKL until 1955 (in Sweden). Arro, K. Eesti Korporatsioonide Liit, 34.

93 Korp! Leola letter to Korp! Rotalia, ERA, 2028-1-3, 15 and to Korp! Väinla, ERA, 2035-1-1, 11.

94 EKL esinduskogu protokoll nr 144, 10.10.1939. - EAA, 1761-1-13, 91.

95 Postimees, 1.11.1939, 6.

96 EKL esinduskogu protokoll nr 145, 22.11.1939. - EAA, 1761-1-13, 93-94.

97 EKL esinduskogu protokoll nr 146, 28.11.1939. - EAA, 1761-1-13, 96. 
made, but as Korp! Estica still did not have an official decision on this matter, the final decision could not be made. But a provisional decision was reached: the Representative Board of the EKL would hear all member Corps on this matter and recommend to the rules committee that chapter 4 of the $E K L$ rule drafts, dealing with giving of satisfaction with arms, would be expunged. This was accepted unanimously. $^{98}$

The Representative Board of EKL had only three meetings left before it was banned by the Soviet authorities, and no official final decision in this problem took place, despite a notable unison. The matter of duels and mensuurs was solved by a larger force, as the whole existence of Estonian student Corps ended with the Soviet occupation, and the new university law did not allow Corps to exist in the Soviet academic society at the State University of Tartu. ${ }^{99}$

\section{GERMAN INFLUENCE ON ESTONIAN STUDENT SONG TRADITION AND EXPORT TO FINLAND}

Many still popular German student songs were translated into Estonian so long ago that they are often considered to be Estonian originals. But some of them can be traced back to Germany thru Latvia, where they had also been translated into the local language. And many of these songs found their way to Finnish student tradition thru active exchange with Estonian organizations, mainly during the 1930s and again in the 1990s.

'Strömt herbei, ihr Völkerscharen' is an old German student song from the shores of the Rhine. The lyrics by Otto Inkermann are from 1848, and the melody by Peter Johann Peters is dated 1867. ${ }^{100}$ The Dorpater Burschenlieder from 1882 has naturally the German original. ${ }^{101}$ A Latvian student songbook from 1992 gives C. O. Sternau as the author of the lyrics for the Latvian version called 'Pulcejaties, latvju deli', but the year is the same, $1848 .{ }^{102}$

Next time we meet the same song in Estonia with Estonian lyrics in a student songbook Üliõpilaslaulik from 1924. It was translated by University of Tartu philology student Malle Kuusik, and went by the name 'Rahvahulgad, tulge $k o k k u$ '. ${ }^{103}$ The translation is very true to the German original, but the Rhine has changed into local Tartur river, the Emajõgi. At the time of visible animosity towards many German aspects of everyday life, like family names ${ }^{104}$, it is also notable that the German origin of the song was mentioned with the translator's name in the 1935 Tudengilaulik. ${ }^{105}$

EKL esinduskogu protokoll nr 146, 28.11.1939. - EAA, 1761-1-13, 97.

ENSV Teataja nr 24, 11.10.1940, 205-213.

http://www.ingeb.org/lieder/stromthe.html, 5.10.2003.

Seeler, N. Th. Dorpater Burschenliederbuch. Dorpat, 1882, 130.

Dziesmas studentiem. Riga, 1992.

Üliõpilaslaulik. Tallinn, 1924.

See Üliõpilasleht in 1934.

Tudengilaulik. Tartu, 1934, 250. 
The song appears with Estonian lyrics in Finnish songbooks during the 1930s, when the co-operation between Estonian Corps and Finnish student nations at the University of Helsinki was very active. We find it in the Pohjois-Pohjalaisten Laulukirja from $1934^{106}$, without any mention of its German origin. The earlier edition of the same songbook from $1927^{107}$ did not yet have any Estonian songs at all and just two German songs. This helps to time the beginning of Estonian influence at the Pohjois-Pohjalainen osakunta, as the friendship treaty with Eesti Üliõpilaste Selts in Tartu was signed in 1928, the first Estonian-Finnish friendship treaty between student organizations. ${ }^{108}$ This song, learned obviously from Estonian friends, became popular very fast and appeared also in other student songbooks of Finnish-speaking student organizations, like Wiipurilaisen osakunnan Laulukirja from 1939. ${ }^{109}$ And the song is still in the newest editions of student nation's songbooks, like Varsinaissuomalaisen osakunnan laulukirja from $2000^{110}$ as well as Pohjois-Pohjalaisten Laulukirja from $1994 .^{111}$

One peculiarity about 'Strömt herbei' is its appearance in the 1954 edition of the previously mentioned Pohjois-Pohjalaisten Laulukirja, this time in German and under the name of 'Rheinlied'. ${ }^{112}$ When two earlier publications had been with Estonian lyrics, the change back to the original German text is noteworthy. Especially when one recalls that in the 1994 edition the language had changed back to Estonian. The answer lies in the Finnish political climate: songbooks of 1927 and 1934 were published during the time when Estonia was an independent state, as well as in 1994. But the 1954 edition was published during the Soviet occupation of Estonia, and thus it was perhaps considered to be unwise to advertise connections to independent Estonia and its patriotic student organizations which were banned by the USSR authorities in 1940 - even if the connections were in the form of a song in Estonian language. Thus the temporary reversion to German lyrics can be seen as an example of political 'over-correctness'.

Another interesting appearance of 'Strömt herbei' is the Finnish version of the lyrics in Wiipurilaisen osakunnan laulukirja in 1939. ${ }^{113}$ This time the Rhine and the Emajõgi have turned into Aura-river in the old university town of Turku, which seems like a strange choice of location for an organization which is based in Helsinki and its university. The title 'Siskot, veikot, kohdatkaamme' is quite true to the original, but still Auvo Hirsjärvi is named as the translator, and not the author, of the lyrics. The song does not appear in any other songbook from the same period, the Estonian lyrics seem to dominate.

\footnotetext{
106 Pohjois-Pohjalaisten Laulukirja. Jyväskylä, 1934, 240.

107 Pohjois-Pohjalaisten Lauluja. Helsinki, 1927.

108 Vuorjoki, R. Yleisvaiheet. Pohjois-Pohjalainen Osakunta 1907-1932. Helsinki, 1932, 90.

109 Lisäys Wiipurilaisen osakunnan laulukirjaan. Helsinki, 1939, 226.

110 Varsinaissuomalaisen osakunnan laulukirja. Turku, 2000, 34.

111 Pohjois-Pohjalaisten Laulukirja. Tartu, 1994, 236.

112 Pohjois-Pohjalaisten Laulukirja. Jyväskylä, 1954, 221.

113 Lisäys Wiipurilaisen osakunnan laulukirjaan, 1939, 226.
} 


\section{OTHER TRAVELLING GERMAN STUDENT SONGS}

'Strömt herbei' is naturally not the only German student song, which has travelled all the way to Latvia and Estonia. Another fine example is 'Rückblick eines altes Burschen' or ' $O$, Alte Burschenherrlichkeit'. Its roots can be found in the 18th century Jena, where the chorus 'O jerum jerum jerum' was published in Jenaer Blatt in 1763. Other data of the song are quite vague, but it seems to be a result of certain musical and lyrical evolution. ${ }^{114}$

In Latvia the song has at least two translations. 'Ak, veca bursu grezniba' in the 1992 songbook was without a translator but named Eugen Höfling as the original author and 1825 as the year. ${ }^{115}$ 'Ak, bursu sena godiba' was published in 1936 with P. Stiprais as the translator. ${ }^{116}$

Dorpater Burschenlieder from 1882 has 'O, Alte Burschenherrlichkeit' with 7 verses and Eugen Höfling as the author. ${ }^{117}$ In 1924 Üliõpilaslaulik the song is not included, but Laulik üliópilastele in 1929 has the Estonian lyrics under the name of 'O bursi hiilgus endine' ${ }^{118}$ And in the 1934 Tudengilaulik the song is in German, again, but this time with only 6 verses. ${ }^{119}$ Korporatsioon Ugala songbook from 1993 has returned to the Estonian lyrics with full 7 verses. ${ }^{120}$

The jump to Finland was made quite early, 'O, Alte Burschenherrlichkeit' can be found in Pohjois-Pohjalaisia Lauluja of 1927 with 6 verses. ${ }^{121}$ German has remained the language of this song until today. This song is probably one of the few German songs which do not directly seem to depend on Finno-Estonian student co-operation for its wide popularity. It has also found its way into Swedish song tradition with the name ' $O$ gamla klang- och jubeltid', 6 verses and August Lindh as the translator. ${ }^{122}$

\section{CONCLUSIONS}

Until the birth of the Republic of Estonia in 1918 the German student traditions had established themselves not only in the Baltic German Corps, which had carried them to Tartu, but also in the Estonian national Corps, which had started to emerge in 1900. The German influence was also present in other national Corps traditions, as well as in the female Corps.

\footnotetext{
114 http://staff-www.uni-marburg.de/ nail/burschen.htm 5.10.2003.

115 Dziesmas studentiem, 1992.

116 Universitas, 10.3.1936, 4, 82.

117 Seeler, N. Th. Dorpater Burschenlieder, 118.

118 Laulik üliõpilastele, 150.

119 Tudengilaulik, 373.

120 Korporatsioon Ugala laulik. Tartu, 1993, 233.

121 Pohjois-Pohjalaisia Lauluja, 1927, 36.

122 Teknologföreningens sångbok. Jyväskylä, 1994, 11.
} 
The traditions flourished in two parallel student cultures from 1900 to the late 1930s, when Estonian Corps in corpore took steps to change their tradition in certain parts. It is interesting that the tradition of giving satisfaction with arms, as well as the whole tradition of fencing, was labeled as German despite its international background even in Estonia ${ }^{123}$, and thus seen as a foreign element in Estonian culture.

Yet at the same time other strong features of the German and Baltic German tradition flourished in the same Estonian Corps. Interesting comparison can be made by looking more closely into the student song traditions. In musical field the clearly German tradition was practically not limited at all, except for translations, which became necessary as the society became more Estonian-speaking instead of German. In fact the German tradition proved its viability by becoming an academic export from Estonia to Finland, which in fact had her own ties with German universities but actually received the major bulk of German student songs via Estonia, mainly during the 1930s.

The development was stopped by several events, the biggest being the Soviet occupation of Estonia in June 1940, which annihilated the old Estonian student organizations in their homeland and forced them into decades of existence in exile and partly underground in Soviet Estonia. The other major factor was the Umsiedlung of the Baltic Germans, mainly in fall 1939. This deprived the student culture of the bearers of the original imported and adapted student customs of Germany, which in time became an integral part of Estonian student culture.

It is impossible to say if the denunciation process of German traditions, or traditions labeled as German, would have spread on from the tradition of duels and satisfaction-giving. The songs were gradually translated, the Corps language was also often translated but no visible movement towards total purification of German elements can be found within the Estonian Corps.

123 Lotman, J. Vestlusi vene kultuurist I. Tallinn, 2003, 241-265.

\section{SAKSA MÕJUST EESTI JA BALTISAKSA KORPORATSIOONIDES TARTUS}

\section{Tiina METSO}

Saksa traditsioonid domineerisid Tartu ülikooli tudengielus ülikooli taasavamisest 1802 kuni baltisakslaste lahkumiseni Eestist 1939. aastal.

Teatakse üsna hästi, et mitmed üliõpilastraditsioonid Eestis olid järginud saksa traditsioone. Siin võime nimetada järgmisi märksõnu: korporatsioonid, mensuur, laulujuhatamine, laulud jne. Saksa traditsioonide omaksvõtmine baltisaksa üliõpilasorganisatsioonide poolt on mõistetav ja loogiline. Samas pole hästi teada, kuidas mõjutasid baltisaksa korporatsioonid eesti korporatsioonide traditsioone. 
Pole selgitatud ka seda, kui palju tuginesid eesti ja samuti teiste rahvaste Eestis tegutsevad korporatsioonid baltisaksa korporatsioonide traditsioonidele. Korporatsioonide vorm polnud siiski kaugeltki ainus traditsioon, mis uute mittesaksa üliõpilasorganisatsioonide poolt üle võeti, kui need 20. sajandi alguse Tartus tekkisid.

Saksa traditsioonide omaksvõtmise kõrval on oluline vaadelda ka traditsioone, mis heideti kõrvale või millest loobuti pärast iseseisva Eesti riigi teket 1918. aastal. Saksa-vastasus oli omane eesti rahva enamikule ja nii oli täiesti loomulik, et see kõik mõjutas ka eesti üliõpilaselu. Saksa ja saksapäraseid nimesid muudeti eesti nimedeks riiklikust aktsioonist lähtudes ka ülikoolis.

Üliõpilaskorporatsioonid lõpetasid saksa keeles laulude laulmise ja nende asemele tulid laulud, mis olid tõlgitud saksa keelest eesti keelde. Eesti korporatsioonide sisemises kõnepruugis püüti loobuda germanismidest. 1939. aastal alustasid eesti meeskorporatsioonid ühist aktsiooni, et kaotada auküsimuste lahendamine relvade abil. Seda traditsiooni nimetati saksa omaks, vaatamata sellele et selle rahvusvaheline päritolu oli olnud akadeemilistele ringkondadele teada. 